\title{
Article
}

http://dx.doi.org/10.11646/phytotaxa.173.4.3

\section{Two new Sabicea (Rubiaceae) species from West Central Africa: Sabicea bullata and Sabicea urniformis}

\author{
LISE A. ZEMAGHO ${ }^{1,2}$, OLIVIER LACHENAUD ${ }^{3}$, STEVEN DESSEIN ${ }^{3}$, SIGRID LIEDE-SCHUMANN ${ }^{2}$ \& \\ BONAVENTURE SONKE ${ }^{1,4,5}$ \\ 'Plant Systematic and Ecology Laboratory, Higher Teachers' Training College, University of Yaoundé I, P.O. Box 047, Yaoundé, Cameroon; \\ Email:lisemez@yahoo.fr, bonaventuresonke@ens.cm \\ ${ }^{2}$ Department of Plant Systematics, University of Bayreuth, 95440 Bayreuth, Germany; \\ Email: sigrid.liede@uni-bayreuth.de \\ ${ }^{3}$ Botanic Garden Meise, Domein van Bouchout, BE-1860 Meise, Belgium; \\ Email:steven.dessein@br.fgov.be,olachena@ulb.ac.be \\ ${ }^{4}$ Service Evolution Biologique et Ecologie, Université Libre de Bruxelles - ULB, 50 Av. F. Roosevelt, CP160/12, 1050 Bruxelles, Belgique \\ ${ }^{5}$ Missouri Botanical Garden, Africa \& Madagascar Department, P.O. Box 299, 63166-0299, Saint Louis, Missouri, USA
}

\begin{abstract}
Two distinctive new species of Sabicea (Rubiaceae) from the Lower Guinea region are described and illustrated. Sabicea bullata is easily recognized by its cordate leaves, which are strongly bullate above, and its sessile glomerulate inflorescences. It is restricted to the Rumpi Hills and Bakossi Mountains, in southwestern Cameroon. Sabicea urniformis, from southern Gabon and Congo-Brazzaville, is remarkable in having discolorous leaves and an urn-shaped involucre with bracts shortly connate at the base.

Detailed descriptions and botanical drawings are provided, conservation status assessed and taxonomic affinities discussed.
\end{abstract}

Key words: Conservation status, Lower Guinea, Rumpi Hills, IUCN Red List Categories

\section{Introduction}

Sabicea Aublet (1775: 192) is a large genus of the Rubiaceae family and includes ca. 145 species (Govaerts et al. 2013). The two main centers of diversity are tropical Africa (ca. 85 species) and South America (ca. 54 species) (Khan et al. 2008); the genus also occurs in Madagascar (6 spp.) (Razafimandimbison \& Miller, 1999) and Sri Lanka (1 sp.) (Khan et al. 2008).

The delimitation of Sabicea, especially in Africa, has been controversial. Halle $(1963,1966)$ regarded Sabicea to consist only of species with twining habit and 5-locular ovaries, and separated the genera Stipularia Palisot-Beauvois (1807: 26), Ecpoma Schumann (1896: 430) and Pseudosabicea N. Hallé (1963: 170), which have a non-twining habit and (except in Stipularia) 2-locular ovaries. Based on phylogenetic data, Khan et al. (2008) united these satellite genera with Sabicea. This largely follows the earlier treatments of Wernham (1914, who however kept Stipularia distinct) and Hepper (1958). Sabicea in the broad sense is easily characterized by the following combination of characters: absence of raphides, valvate corolla aestivation, axillary inflorescences and fleshy fruits with numerous small seeds (Dessein et al. 2001, Khan et al. 2008).

The genus Sabicea s.l. belongs to tribe Sabiceeae. Based on nrITS and trnT-F sequence data, Khan et al. (2008) also included in this group the genera Hekistocarpa Hooker (1873: 1151), Tamridaea Bremer \& Thulin (1998: 85) and Virectaria Bremekamp (1952: 21), although this broad circumscription of Sabiceeae s.1. is not supported by any morphological synapomorphy. Dessein et al. (2001) treated these three genera as a separate tribe, Virectarieae, a position supported by rps 16 intron sequences.

In Africa, Sabicea s.l. is most diverse in the Lower and Upper Guinea Domains, with only few species in the Congolia Domain and in the other African phytoregions of White (1979). Although valuable regional treatments have been provided by Hepper \& Keay (1963) for West Africa, Hallé (1966) for Gabon and Verdcourt \& Bridson (1988) 


\section{References}

Anonymous (1962) Systematics Association Committee for descriptive biological terminology II. Terminology of simple symmetrical plane shapes (chart 1a). Taxon 11: 145-156.

http://dx.doi.org/10.2307/1216718

Aublet, J.B.C.F. (1775) Histoire des plantes de la Guiane Françoise. Tome I. Didot jeune, London and Paris, 621 pp.

Bachman, S., Moat, J., Hill, A.W., De la Torre, J. \& Scott, B. (2011) Supporting Red List Threat assessments with GeoCAT: geospatial conservation assessment tool. Zookeys 150: 117-126.

http://dx.doi.org/10.3897/zookeys.150.2109

Bremekamp, C.E.B. (1952) The African species of Oldenlandia L. sensu Hiern et K. Schumann. Verhandelingen der Koninklijke Nederlandse Akademie van Wetenschappen. Afd. Natuurkunde, Tweende Reeks, LVIII, no 2, North-Holland Publishing Compagny, Amsterdam, 297 pp.

Bremer, B. \& Thulin, M. (1998) Collapse of Isertieae, re-establishment of Mussaendeae and a new genus of Sabiceeae (Rubiaceae): phylogenetic relationships based on rbcL data. Plant Systematics and Evolution 211: 71-92.

Cheek, M., Pollard, B.J., Darbyshire, I., Onana, J.-M. \& Wild, C. (2004) The plants of Kupe, Mwanenguba and the Bakossi Mountains, Cameroon: a conservation checklist. Kew, Royal Botanic Gardens, 508 pp.

Dessein, S., Andersson, L., Robbrecht, E. \& Smets, E. (2001) Hekistocarpa (Rubiaceae): A member of an emended tribe Virectarieae. Plant Systematics and Evolution 229: 59-78.

http://dx.doi.org/10.1007/s006060170018

Govaerts, R., Ruhsam, M., Andersson, L., Robbrecht, E., Bridson, D., Davis, A., Schanzer, I. \& Sonké, B. (2013) World Checklist of Rubiaceae, The Board of Trustees of the Royal Botanic Gardens, Kew. Available from: http://www.kew.org/wcsp/ (accessed: 16 November 2013).

Hallé, N. (1963) Délimitation des genres Sabicea Aubl. et Ecpoma K.Schum. en regard d'un genre nouveau: Pseudosabicea (MussaendeaeRubiaceae). Adansonia, sér. 2, 3: 168-177.

Hallé, N. (1964) Complément à l'étude du genre Pseudosabicea N.Hallé (Rubiceae). Bulletin Jardin Botanique État Bruxelles 34: 397402.

http://dx.doi.org/10.2307/3667324

Hallé, N. (1966) Flore du Gabon. Vol. 12. Rubiacées (1e partie). Muséum National d'Histoire Naturelle, Paris, 278 pp.

Hepper, F.N. (1958) Sabicea Aubl. and Stipularia P. Beauv. (Rubiaceae-Mussaendeae) in Tropical Africa. Kew Bulletin 13: $289-294$. http://dx.doi.org/10.2307/4109534

Hepper, F.N. \& Keay, R.W.J. (1963) Rubiaceae. In: F. N. Hepper (Ed.) Flora of Tropical Africa. Vol. 2, Crown Agents for Oversea Governments and Administrations, Millbank, London, pp. 104-224.

Hijmans, R.J., Guarino, L., Cruz, M. \& Rojas, E. (2001) Computer tools for spatial analysis of plant genetic resources data: 1. DIVA-GIS. Plant Genetics. Resources. Newsletter. 127:15-19.

Hooker, J.D. (1849) Niger Flora. London, 587 pp.

Hooker, J.D. (1873) Hekistocarpa minutiflora. Icones Planterum 14: t. 1151.

IUCN (2012) IUCN Red List Categories, Version 3.1. Second Edition. Prepared by the IUCN Species Survival Commission. IUCN, Gland, Switzerland and Cambridge, UK. Downloadable from: http://jr.iucnredlist.org/documents/redlust_cats_crit_en.pdf(accessed: 4 august 2013).

IUCN Standards and Petitions Subcommittee (2013) Guidelines for Using the IUCN Red List Categories and Criteria. Version 10 (February 2013). Prepared by the Standards and Petitions Subcommittee. Downloadable from: http://www.iucnredlist.org/documents/ RedListGuidelines.pdf (accessed: 04/08/2013).

Khan, S.A., Razafimandimbison, S.G., Bremer, B. \& Liede-Schumann, S. (2008) Sabiceeae and Virectarieae (Rubiaceae, Ixoroideae): one or two tribes? New tribal and generic circumscriptions of Sabiceeae and biogeography of Sabicea s.1. Taxon 57: 1-17.

Krause, K. (1917) Beiträge zur Flora von Afrika XLVI, Rubiaceae africanae. Botanische Jahrbücher für Systematik, Pflanzengeschichte und Pflanzengeographie 54: 357

Mildbraed, G.W.J. (1922) Wissenschaftiche Ergebnisse der zweiten Deutschen Zentral-Africa-Expedition 1910-1911 unter Führung Adolf Friedrichs, Herzogs zu Mecklenburg. Band II. Klinkhardt \& Biermann, Leipzig, 202 pp.

Palisot-Beauvois, A.M.F.J. (1810) [1807] Stipulaire. Stipularia, Fam. des Rubiacées. In: Flore d'Oware et de Bénin en Afrique. Imprimerie de Fain et compagnie, Paris, p. 26.

Razafimandimbison, S.G. \& Miller, J. (1999) New taxa and nomenclatural notes on the flora of the Marojejy Massif, Madagascar. III. Rubiaceae. A new species of Sabicea. Adansonia sér. 3. 21: 41-45.

Robbrecht, E. (1988) Tropical woody Rubiaceae. Characteristics, features and progressions. Contribution to a new subfamilial classification. 
Opera Botanica Belgica 1: 1-271.

Schumann, K. (1896) [1897] Beiträge zur Flora von Afrika, XIII, Rubiaceae africanae. In: Engler A. (Ed.) Botanische Jahrbücher für Systematik, Pflanzengeschichte und Pflanzengeographie 23. W. Engelmann, Leipzig, Germany, pp: 412-470.

Thiers, B. (2010) Index Herbariorum: A global directory of public herbaria and associated staff, New York Botanical Garden's Virtual Herbarium. Available from: http://sweetgum.nybg.org/ih/ (accessed: 01/10/2010).

Verdcourt, B. \& Bridson, V. (1988) Rubiaceae (part II). In: Polhill R.M. (Ed.) Flora of Tropical East Africa. Balkema, Rotterdam, p 747.

Wernham, H.F. (1914) A monograph of the genus Sabicea. London, British Museum (Natural History), 82 pp.

White, F. (1979) The Guineo-Congolian Region and its relationships to other phytochoria. Bulletin du Jardin Botanique National de Belgique 49: 11-55.

http://dx.doi.org/10.2307/3667815 